Indeed, judging from the small amount of damage done to buildings in which flat or square stones and flat floors have been used, I should doubt whether the shock was much more severe than that which not long ago damaged the brick buildings in East Anglia.

At both Oneglia and Diano Marina the building material is usually rounded stones from the beach, or rubble with stones of all shapes and sizes. The stucco is apparently expected to make good any deficiencies. Besides this the floors are nearly always brick arches abutting against the vertical walls, without any reference to other lateral support. Most of these houses are three or four stories high. Of course any vibration affecting buildings of this construction will split the walls in all directions, for besides the lateral thrust of the arches, the walls are full of wedge-shaped stones ready to slip into any fissures which may form.

The complication caused by these arched floors makes it very difficult to trace the direction or angle of emergence of the shock.

Oneglia, March I3

\section{Scorpion Virus}

Allow me to state that the results of my experiments on Cape scorpions are in full accord with Prof. Bourne's conclusion that the poison of the scorpion has no fatal effect on the same individual or another individual of the same or even of another species. Speaking before the South African Philosophical Society in February 1883, I said :- "Members of the Society will see on the table a scorpion of the larger (Cape) species. That scorpion I caught at I I o'clock this morning. I at once pierced him in three places with his own sting, on which in each case there was a drop of poison. In the last inoculation I held the sting in the wound, and squeezing the 'bulb of the sting' with the pincers forcibly injected poison. The creature is alive and active" (Proceedings for 1883 ). These and subsequent experiments, however, led me to believe that the poison has some effect, causing sluggishness and torpor for a while. I quite agree with Prof. Bourne that it is physically possible for a scorpion to sting itself in a vulnerable place; and though I never was able to observe the infliction of a wound on itself by any scorpion, I can well believe that this is possible, but, I am convinced, wholly accidental.

I found also that the poison of the ring-hals snake (Naja hamachates) was not fatal when inoculated in the same individual or another individual of the same species.

University College, Bristol

C. LL OYD MORGAN

\section{The Supposed Myzostoma-cysts in Antedon rosacea}

Some eighteen months ago I called attention in these columns (vol. xxxii. p. 39 r, and vol. xxxiii. p. 8) to certain malformations which I had discovered on the pinnules of Antedon rosaced from various British localities. They often take the form of small cysts which are very like those produced by encysting Myzostomida on the arms and pinnules of various Crinoids from the Pacific; and as no other cyst-builders but Myzostoma were then known to infest the Crinoids, the inference seemed a natural one that the cysts on the pinnules of Antedon rosacea had been produced by a small member of this genus. I subsequently found several more cysts on some examples of Antedon rosacea which were dredged at Gibraltar by the Italian corvette Vettor Pisani, and the whole collection was sent to my friend Prof L. von Graff for examination.

To our great surprise, however, he has not found a single Myzostoma in any one of the fourteen malformations of the pinnules, whether cysts or otherwise, which he has opened; and "the new British Myzostoma" must therefore be disestablished.

But what, then, has been the cause of these malformations? Prof. von Graff has found them to be always associated with the presence of a minute globular body, which has the appearance of an egg that has undergone superficial cleavage, bnt yet exhibits no trace of nuclei when stained. It is impossible to decicie at present what this structure may be. Prof. von Graff has described it more fully in a "Supplementary Report on the Myzostomida of the Challenger Expedition" which he has just completed. But its nature seens to be as problematical as that of the sacculi ; and fresh material, not spirit specimens, must be examined before we can expect to learn much more about it. In any case, however, it would seem that we have to deal with a hitherto urknown parasite of the Crinoids, which is capable of producing modifications in the calcareous tissues of the arms and pinnules, of essentially the same character as those caused by Myzostoma, though of smaller size.

I would commend the question to the attention of those naturalists who may meet with Antedon rosacea in the dredgings of the ensuing season; and in order that they may know how to catch their hare, I shall be most happy to forward specimens of the cysts to anyone who desires to become acquainted with their external appearance. I may add that the largest cysts I have seen are on Comatulæ from the Cumbrae, Milford Haven, and Gibraltar ; while I bave no knowledge of their occurrence either at Naples or anywhere else in the Mediterranean.

Eton College

P. Herbert Carpenter

\section{On some Observations on Palæobutany in Goebel's "Outlines of Classification and Special Morphology of Plants"}

THE few modern authors of botanical text-books who have ventured to summarise recent palæobotanical researches have achieved but moderate success. These authors have too little knowledge of the rapid progress of the study of fossil plants during the last few years to make success posible; hence, their summaries, if not absolutely inaccurate, are usually misleading. So long as these errors are confined to works published in Continental languages, British palæobotanists need not take the trouble to correct them. But the case is altered when English translations of these books appear amongst us. Palæobotany has nowhere made greater progress during the last few years than with ourselves. Many errors have been corrected, and new truths, results of careful and prolonged investigations, have taken their place. With the more important of these new discoveries many of our younger students of geology are now familiar. It is desirable that what they have been taught should not be contradicted by the utterances of authors ignorant of the subjects upon which they venture to express an opinion.

Some little time ago Dr. Goebel, of Rostock, published a volume which was virtually a new edition of Book II. of Sachs's "Lehrbuch der Botanik," and an English translation of this volume, made by Mr. H. E. F. Garnsey, and revised by Prof. I. B. Balfour, has just appeared. Dr. Goebel's volume contains some references to the Palæozoic flora which are seriously behind the times. To allow these statements to reach our students uncorrected will do harm, because they must suggest to those students that certain questions are still open and debatable which cannot now be regarded as such.

Had I not unfortunately misunderstood a wish expressed by my friend Prof. Balfour, some explanatory footnotes would have been introduced into the above volume, which would have rendered this communication unnecessary.

On p. 193 of the translation we find the following statement :"Other groups are the Sphenophylleæ, Lepidodendreæ, and Sigillariex, the first of which are only heterosporous Lyc spodiacex." We have no reasons for concluding that Sphenophyllum is Lycopodiaceous, still less that it is heterosporous. 'This latter statement rests upon M. Renault's interpretation of a minute mullicellular fragment which he observed in a sporangium, and which he believed to be a macrospore; it could not be this, since the exosporium of a macrospore is a unicellular organism. On the other hand, the Lepidodendra were both homosporous and heterosporous. As to the Sigillariæ, even M. Renault now admits that all the vertically-fluted forms are Lycopodiaceous. The assertion that the Lepidodendra were all heterosporous is repeated on p. 196 . On p. 272 we have a brief paragraph of eight lines remarlable for the number of the inaccurate statements which it contains. I have indicated these inaccuracies by reproducing them in italics.

"The Calamites are Equisetaceæ which appear in the older geological formations, beginning in the Carboniferous Limestone (I), culminating in the Coal-measures, and disappearing in the Permian formation. The spikes of sporangia are either not known, or so badly preserved (Calamostachys) (2), that their structure cannot be determined; it remains doubtful, therefore, Whether they were homosprous or heterosporous forms (3) The stems had neither leaves nor leaf-sheaths, or else these were transitory formati'ns and soon fell off (4). In other respects the structure of the stems resembles that of the Equisetacece (5). 